\title{
Article \\ New Metakaolin-Based Geopolymers with the Addition of Different Types of Waste Stone Powder
}

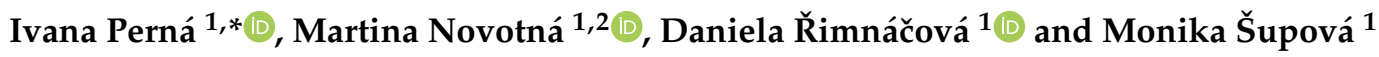 \\ 1 Institute of Rock Structure and Mechanics, The Czech Academy of Sciences, V Holešovičkách 41, \\ 18209 Prague, Czech Republic; novotna@irsm.cas.cz (M.N.); rimnacova@irsm.cas.cz (D. ̌..); \\ supova@irsm.cas.cz (M.Š.) \\ 2 Department of Glass and Ceramics, University of Chemistry and Technology Prague, Technická 5, \\ 16628 Prague, Czech Republic \\ * Correspondence: perna@irsm.cas.cz; Tel.: +420-266009253; Fax: +420-284680105
}

check for updates

Citation: Perná, I.; Novotná, M.; Řimnáčová, D.; Šupová, M. New Metakaolin-Based Geopolymers with the Addition of Different Types of Waste Stone Powder. Crystals 2021, 11, 983. https://doi.org/10.3390/ cryst11080983

Academic Editor: Zhaohui Li

Received: 27 July 2021

Accepted: 18 August 2021

Published: 19 August 2021

Publisher's Note: MDPI stays neutral with regard to jurisdictional claims in published maps and institutional affiliations.

Copyright: (c) 2021 by the authors. Licensee MDPI, Basel, Switzerland. This article is an open access article distributed under the terms and conditions of the Creative Commons Attribution (CC BY) license (https:// creativecommons.org/licenses/by/ $4.0 /)$.

\begin{abstract}
The search for new alternative raw materials and their subsequent use supports the sustainability of natural resources. This article describes the use of waste stone powder (WSP) in geopolymer synthesis. Five different types of WSP (feldspar, limestone, marlstone, dolomite, marble) were comprehensively characterized and their influence on the resulting properties (especially mechanical and textural properties, setting time and structure) of metakaolin-based geopolymer composites was investigated. Their comparison with a geopolymer composite containing only quartz sand has revealed that WSP additions have a small but positive effect on the mechanical or textural properties of geopolymers. Moreover, setting time measurements have shown that waste stone powders can be used as an accelerator of geopolymer reaction solidification. The results demonstrated that the mentioned types of WSP, previously landfilled, can be used for the preparation of geopolymers. This can help reduce the environmental burden.
\end{abstract}

Keywords: geopolymer; waste stone powder; recycling; characterization; mechanical properties; textural properties

\section{Introduction}

Sustainability is becoming a keyword in all aspects of human life. Research often focuses on the development of new and more efficient methods and technologies for using natural resources as well as on the possibilities of exploiting hitherto neglected resources such as waste materials or raw materials that cannot be used classically. Not only does the use of these waste materials save natural resources, but it also has ecological and economic benefits. Organic and inorganic waste materials are meaningfully reused in other ways than landfilling, e.g., by thermal recovery [1,2], in construction, alternative binder and composite production [3-7], or as potentially effective adsorption materials [8,9].

This article focuses on waste materials from natural stone processing. The extraction and processing of natural stones are among the earliest human activities. Stonemasons and sculptors in all cultures have participated in the creation of buildings, monuments, statues and other artifacts. During the extraction of natural stone in quarries, its handling, transportation and especially final processing, waste materials are generated. Larger broken pieces or cuttings can often be used for other applications, e.g., for decorative or horticultural purposes. On the contrary, fine powder generated during stone cutting and grinding is used minimally. The waste stone powder (WSP) slurry is usually filter-pressed and subsequently landfilled. This material has recently begun to be partially used in mortar and concrete or in the stabilization of clayey soils [10-12].

One of the ways to reuse and recycle very fine waste stone powder is its application to geopolymer materials, known since 1979. Since then, these innovative materials, their 
synthesis and properties have been studied worldwide [13-16]. Their structure is predominantly amorphous and consists of aluminate and silicate units (-Si-O-Al-O-) in different $\mathrm{Si} / \mathrm{Al}$ ratios [14,17-19]. An appropriate choice of raw materials and fillers and/or additives significantly affects the resulting properties of geopolymer composites, in particular heat and fire resistance, high resistance to aggressive media, high early strength, and mechanical properties comparable with other inorganic binders. The presence of pores of different sizes in the final products could affect the mentioned properties both negatively and positively. Therefore, textural analyses should be provided. Additionally, geopolymers are able to accept different types of materials into their network regardless of granulometry.

The influence of various types of active or inert fillers in the different matrices (involved or not in the geopolymer reaction, respectively) has been studied by many researchers [20-22]. Perez-Cortes et al. [23] investigated the addition of limestone in metakaolin-based geopolymers. According to Ref. [24], geopolymer composites were prepared with dolomite quarry dust using fly ash-based geopolymer. The properties of marble waste in connection with the metakaolin via alkali activation were also studied [25]. However, the comparison of five different WSP (feldspar, limestone, marlstone, dolomite, marble) has not been reported so far.

This article presents a characterization of five different types of WSP (feldspar, limestone, marlstone, dolomite, marble) and investigates their influence on the properties of metakaolin-based geopolymer composites. It may be assumed that the addition of WSP will affect the resulting properties of geopolymers, especially setting time, structure, mechanical and textural properties.

\section{Experimental Part}

\subsection{Materials}

For the production of the standard geopolymer samples, industrially supplied raw materials were selected, including clay material L05 (ČLUZ a.s., Nové Strašecí, Czech Republic), quartz sand STJ 25 with the grain-size range of 0.063-0.315 mm (Sklopísek Střeleč, a.s., Střeleč, Czech Republic), potassium silicate solution 3.0 (Vodní sklo, a.s., Prague, Czech Republic), and potassium hydroxide (KOH; Penta, s.r.o., Prague, Czech Republic). These products have their parameters (e.g., chemical composition, purity, and particle size) guaranteed by their producers. The chemical compositions of the clay material and quartz sand are presented in Table 1, where they are complemented by loss on ignition (LOI).

Table 1. Chemical analysis of the industrially supplied raw materials (the main oxides in wt. \%).

\begin{tabular}{cccccccccc}
\hline Material/Oxide & $\mathrm{Al}_{\mathbf{2}} \mathbf{O}_{\mathbf{3}}$ & $\mathrm{SiO}_{\mathbf{2}}$ & $\mathbf{C a O}$ & $\mathrm{Na}_{\mathbf{2}} \mathbf{O}$ & $\mathbf{K}_{\mathbf{2}} \mathbf{O}$ & $\mathbf{M g O}$ & $\mathbf{F e}_{\mathbf{2}} \mathbf{O}_{\mathbf{3}}$ & $\mathrm{TiO}_{\mathbf{2}}$ & $\mathrm{LOI}$ \\
\hline L05 & 41.99 & 50.28 & 0.14 & $<0.11$ & 0.59 & 0.138 & 1.03 & 1.522 & 3.65 \\
Quartz sand & 0.3 & 99.3 & $<0.001$ & $<0.001$ & $<0.001$ & $<0.001$ & 0.025 & 0.15 & 0.1 \\
\hline
\end{tabular}

The types of waste stone powder used in the experiments (feldspar, limestone, dolomite, marble, marlstone) come from Czech stone-processing plants. The dried powder was used in the original granulometry, i.e., it was not further pulverized. The chemical compositions and particle size analyses of the various types are summarized in Table 2 and Table S1 (Supplementary Materials), respectively.

Table 2. Chemical analyses of the various types of waste stone powder (the main oxides in wt. \%).

\begin{tabular}{cccccccccc}
\hline Material/Oxide & $\mathbf{A l}_{\mathbf{2}} \mathbf{O}_{\mathbf{3}}$ & $\mathbf{S i O}_{\mathbf{2}}$ & $\mathbf{C a O}$ & $\mathbf{N a}_{\mathbf{2}} \mathbf{O}$ & $\mathbf{K}_{\mathbf{2}} \mathbf{O}$ & $\mathbf{M g O}$ & $\mathbf{F e}_{\mathbf{2}} \mathbf{O}_{\mathbf{3}}$ & $\mathbf{T i O}_{\mathbf{2}}$ & $\mathbf{L O I}$ \\
\hline Dolomite & 0.34 & 1.21 & 37.39 & $<0.11$ & 0.15 & 14.33 & 0.33 & 0.02 & 46.05 \\
Marble & 0.78 & 1.93 & 51.24 & $<0.11$ & 0.22 & 2.39 & 0.63 & 0.05 & 42.51 \\
Marlstone & 4.45 & 57.85 & 19.69 & $<0.11$ & 0.90 & 0.55 & 1.94 & 0.28 & 13.88 \\
Limestone & 0.21 & 0.39 & 55.04 & $<0.11$ & 0.07 & 0.47 & 0.36 & 0.02 & 43.31 \\
Feldspar & 17.42 & 68.64 & 0.55 & 1.98 & 7.47 & 0.33 & 1.56 & 0.15 & 0.61 \\
\hline
\end{tabular}




\subsection{Sample Preparation}

First, the clay material was thermally treated at $750{ }^{\circ} \mathrm{C}$ for $4 \mathrm{~h}$. Subsequently, it was mixed with an aqueous alkaline solution $\left(\mathrm{SiO}_{2} / \mathrm{K}_{2} \mathrm{O}=1.40, \mathrm{H}_{2} \mathrm{O} / \mathrm{K}_{2} \mathrm{O}=12.43\right)$ with a shaft mixer for $30 \mathrm{~min}$ (the molar ratios of the geopolymer mixture: $\mathrm{SiO}_{2} / \mathrm{Al}_{2} \mathrm{O}_{3}=2.62$, $\mathrm{H}_{2} \mathrm{O} / \mathrm{K}_{2} \mathrm{O}=12.43, \mathrm{~K}_{2} \mathrm{O} / \mathrm{Al}_{2} \mathrm{O}_{3}=0.50$ ). The geopolymer matrix was then transferred to a laboratory mixer with a planetary mixing action, where quartz sand $(42.5 \mathrm{wt}$. \%) or a mixture of quartz sand and stone powder was added to the geopolymer matrix. The A addition of WSP was $8 \mathrm{~g}$ per $50 \mathrm{~g}$ of the clay material L05 (5.6 wt. \%), whereas the B addition was $16 \mathrm{~g}$ of WSP per $50 \mathrm{~g}$ of the same clay material (10.6 wt. \%). After homogenization $(10 \mathrm{~min})$, the geopolymer mass was poured into $40 \times 40 \times 160 \mathrm{~mm}$ molds, which were vibrated ( $5 \mathrm{~min}$ ) to remove unwanted air bubbles. The molds were protected from water evaporation by being covered by a glass panel for $24 \mathrm{~h}$. After that, the solid samples were de-molded and stored for 28 days in plastic bags and further in the air under laboratory conditions. The designation of geopolymer samples and mix design are summarized in Table S2 (Supplementary Materials).

\subsection{Methods}

Chemical composition was determined using a non-destructive $\mathrm{X}$-ray fluorescence (XRF) analyzer (Spectro IQ, Kleve, Germany) equipped with a HOPG Barkla crystal. The instrument has the following parameters: helium atmosphere, the palladium target material, the target angle from the central ray: $-90^{\circ}$, the focal point: a $1 \mathrm{~mm} \times 1 \mathrm{~mm}$ square, the maximum anode dissipation of 50 watts, and 10-cfm forced-air cooling.

The particle-size distribution was measured by a CILAS 920L analyzer equipped with laser-beam reflection. The measurement was performed in an aqueous suspension with the simultaneous use of ultrasound to avoid an agglomeration of the tested particles.

Samples for X-ray diffraction (XRD) analysis were ground to analytical fineness using a McCrone Mill in an ethanol suspension. XRD analyses were performed with a Bruker D8 Advance $\mathrm{X}$-ray diffractometer (Bruker, Billerica, MA, USA) using $\mathrm{Cu} \mathrm{K} \alpha$ radiation and a Lynx Exe XE detector. The powder sample was placed on a flat surface (non-diffractive silicon). Diffraction was recorded in the range of $4-80^{\circ}$, in steps of $0.015^{\circ}$ and with a reading time of $0.8 \mathrm{sec}$ per step. The obtained X-ray diffraction records were qualitatively evaluated in the Diffrac.Eva program (Bruker AXS, 2015) using the ICDD PDF-2 database (ICDD 2018).

The setting time was determined by a fully automatic testing device, Vicatronic (Matest, Viale Mantegna, Italy), according to the Czech Standard ČSN EN 196-3 (Methods for Testing Concrete - Part 3, 2017). The data were evaluated using the VicatWin program (Matest, Viale Mantegna, Italy). The measurement was repeated twice for each geopolymer mixture.

After 28 and 90 days, mechanical properties were measured using prisms with a standard size of $40 \times 40 \times 160 \mathrm{~mm}$ according to the Czech Standard CSN EN 196-1 (Methods for Testing Concrete-Part 1, 2016). The tests were performed on an E152 compression and flexural testing machine with an E170 compression and E172 flexural devices (Matest, Viale Mantegna, Italy). The resulting values of flexural and compressive strength were determined as the arithmetic average of three and six specimens, respectively.

The infrared (FTIR) spectra were measured using an iS50 spectrometer (Nicolet Instruments, Madison, WI, USA) by the attenuated total reflection (ATR) method using a diamond crystal. All the spectra were recorded in the absorption mode at the resolution of $4 \mathrm{~cm}^{-1}$ with 64 scans in the middle infrared range of $4000-400 \mathrm{~cm}^{-1}$. The obtained spectra were processed using the OMNIC software, version 9.

Indirect physicochemical methods, such as gas sorption or mercury intrusion/extrusion porosimetry, are usually used for the complex textural characterization of solid materials. The texture of porous solid materials is usually characterized by the surfaces of micropores in selected size ranges, by pore-size distribution and porosity [26]. 
A volumetric sorption analyzer (Thermo Fisher Scientific, Waltham, MA, USA) was used for the determination of the surface properties of mesopores and macropores, with the main parameter being specific surface area $\left(S_{\mathrm{BET}}\right)$. The measurement was based on nitrogen physisorption at the temperature of $-196^{\circ} \mathrm{C}$ and under pressurization to $100 \mathrm{kPa}$, and the calculation was performed using the BET equation [27].

PASCAL 140 Evo and PASCAL 440 Evo mercury porosimeters (Thermo Fisher Scientific, Waltham, MA, USA) were used for the measurements of the pore-size distributions of meso- and macropores in the size range of $3.5 \mathrm{~nm}-60 \mu \mathrm{m}$, with porosity $(P)$ as the main parameter, and of the surface of meso- and macropores $\left(S_{\mathrm{Hg}}\right)$ [28]. The measurements were based on the intrusion of mercury into pores under increasing pressure and extrusion under decreasing pressure.

An IGA-100 gravimetric sorption analyzer (Hiden Isochema, Warrington, UK) serves for the determination of the surface of micropores $\left(S_{\mathrm{m}}\right)$ from the $\mathrm{CO}_{2}$ adsorption isotherm, where $n$ is the real adsorption capacity at $25^{\circ} \mathrm{C}$ and under the pressure of $0.1 \mathrm{MPa}$. After the degassing and evacuation of the materials at $105^{\circ} \mathrm{C}, \mathrm{CO}_{2}$ adsorption was measured at the temperature of $25^{\circ} \mathrm{C}[29,30]$.

$\mathrm{XRF}, \mathrm{XRD}$ and IR analysis are based on one measurement of a representative sample obtained by quartering. The resulting values of textural analyses proceed from two measurements of representative samples.

\section{Results}

\subsection{Waste Stone Powder Characteristics}

Table 2 shows the chemical analyses of the WSP. The highest amount of alumina is visible for feldspar and marlstone (17.42 wt. \% and $4.45 \mathrm{wt}$. \%, respectively). Major calcium oxide content was identified for limestone and marble (55.04 wt. \% and $51.24 \mathrm{wt}$. \%, respectively). In contrast, the lowest $\mathrm{CaO}$ content was identified in feldspar (0.55 wt. \%). This, together with the quantity of potassium oxide ( $7.47 \mathrm{wt} . \%)$, indicates that it is probably potassium or sodium-potassium feldspar. The lowest value of the loss on ignition (LOI) was observed for feldspar (0.61 wt. \%), followed by marlstone $(13.88 \mathrm{wt}$. \%). The LOI values of the remaining types of WSP are very similar, which results from their carbonate nature.

The particle-size distributions of the waste stone powder, presented in Table S1, have shown differences between the individual types. The highest content of particles smaller than $1 \mu \mathrm{m}$ was observed for marble (12.6 wt. \%) and dolomite (8.06 wt. \%) and the lowest for feldspar (2.81 wt. \%). As evidenced by the D90 value in Table S1, marble has the finest particles of all the WSP studied-90\% of the particles are smaller than $24.45 \mu \mathrm{m}$. Despite the low value of the particles below $1 \mu \mathrm{m}$, feldspar is the second finest waste stone powder $(\mathrm{D} 90=63.56 \mu \mathrm{m})$. In contrast, the highest value of D90 was observed for marlstone and dolomite (118.63 $\mu \mathrm{m}$ and $105.26 \mu \mathrm{m}$, respectively).

The mineralogical analyses of the stone powder (Table S3-Supplementary Materials) correspond to the chemical analyses presented in Table 2. They have confirmed the authenticity of the stone powder. In the case of feldspar, the presence of potassium and sodium-potassium feldspar in the form of microcline and albite was confirmed. At the same time, feldspar also contains quartz, kaolinite and muscovite, the products of its weathering. In the case of limestone powder, the analysis has determined that the material is not pure calcite but one with magnesium admixture (magnesium calcite). Marlstone is predominantly composed of magnesium calcite and quartz, followed by microcline and muscovite. Dolomite powder is composed of dolomite and calcite magnesian with traces of quartz and biotite.

\subsection{Geopolymer Composite Characteristics}

Table 3 shows the results of the initial, final and real setting times (IST, FST and RST, respectively) of geopolymer composites with different types of waste stone powder when RST $=$ FST - IST. As a reference, the IST and FST values of geopolymer with quartz sand 
(STJ 25) were considered (535 and $660 \mathrm{~min}$, respectively). From the results, it is clear that the addition of WSP and mainly the particle size (D50) influence the IST and FST for all types of stone powder except for dolomite, which was removed from the correlation because of its higher $\mathrm{MgO}$ content. For the remaining types of WSP, the smaller WSP particle size (D50) has led to shorter IST and FST $\left(R^{2}=0.9310\right.$ and 0.9854 , respectively), see Figure S1 (Supplementary Materials). The rate of the geopolymer reaction appears to depend on the particle size of the added WSP as in the case of clay materials [31].

Table 3. The setting parameters of geopolymer composites with different types of waste stone powder.

\begin{tabular}{cccc}
\hline & IST & FST & RST \\
\cline { 2 - 4 } & & (min) & 125 \\
STJ 25 & 535 & 660 & 150 \\
Dolomite-A & 530 & 680 & 125 \\
Dolomite-B & 510 & 635 & 110 \\
Marble-A & 385 & 495 & 85 \\
Marble-B & 290 & 375 & 115 \\
Marlstone-A & 540 & 655 & 125 \\
Marlstone-B & 480 & 605 & 170 \\
Limestone-A & 490 & 660 & 95 \\
Limestone-B & 440 & 535 & 115 \\
Feldspar-A & 470 & 585 & 85 \\
Feldspar-B & 430 & 515 &
\end{tabular}

The shortest IST was observed for marble, B addition (290 min). The Marble-B sample also has the shortest FST (375 min) and thus the RST (85 min). Although Feldspar-B and Limestone-B have similar RST (85 min and $95 \mathrm{~min}$, respectively) to Marble-B, their solidification began and ended later (see Table 3). In the case of marlstone, it is remarkable that although solidification in Marlstone-A began one hour later than in Marlstone-B, the resulting total setting time is almost identical (115 min and $125 \mathrm{~min}$, respectively). In addition, marlstone is also the only waste stone powder for which the RST is shorter for the $\mathrm{A}$ addition than for the $\mathrm{B}$ addition.

The geopolymer composites with WSP added were also monitored in terms of mechanical properties. Table 4 shows the values of flexural and compressive strength (the average of three and six specimens, respectively) of the prepared samples after 28 and 90 days with their standard deviations. The lowest values of flexural and compressive strength after 28 days were observed for Dolomite-A sample (4.80 MPa and 72.7 MPa, respectively). After 90 days, however, its results reached the average values of the other samples. The highest value of flexural strength after 28 days was observed for Marble-B (9.59 MPa), but after 90 days this value increased only slightly (10.76 MPa). The best value of flexural strength after 90 days was revealed for the Feldspar-B sample (15.44 MPa). Simultaneously, Feldspar-A and Feldspar-B achieved after 28 days the highest compressive strengths (96.0 $\mathrm{MPa}$ and $94.7 \mathrm{MPa}$, respectively). In contrast, the highest value of compressive strength after 90 days (104.9 MPa) was observed for Dolomite-B. For all samples, the compressive strength after 90 days was higher than $80 \mathrm{MPa}$.

Furthermore, only samples with the B addition of WSP were used for X-ray and IR analyses and for the textural analyses (pore surface areas, porosity, real sorption capacity) because of the higher effect of WSP.

The XRD analyses of geopolymer composites with the B addition have not revealed (Table S4-Supplementary Materials) any formation of new crystalline phases. The presence of an amorphous phase, which is typical of geopolymer materials, has newly been detected in all samples in large amounts in comparison with the results of the original WSP. As expected, after the dilution of the crystalline phases of pure stone powder with geopolymer, the contents of these phases were reduced to minor or even trace. 
Table 4. The mechanical properties of geopolymer composites with different types of waste stone powder.

\begin{tabular}{ccccc}
\hline \multirow{2}{*}{ Sample } & \multicolumn{2}{c}{ Flexural Strength } & \multicolumn{2}{c}{ Compressive Strength } \\
\cline { 2 - 5 } & \multicolumn{2}{c}{$\mathbf{~ ( M P a )}$} & 28 days & $\mathbf{9 0}$ days \\
\cline { 2 - 5 } & $\mathbf{2 8}$ days & $\mathbf{9 0}$ days & $86.6 \pm 4.50$ & $84.6 \pm 6.18$ \\
STJ 25 & $6.44 \pm 0.59$ & $13.03 \pm 0.82$ & $72.7 \pm 6.71$ & $85.5 \pm 5.87$ \\
Dolomite-A & $4.80 \pm 0.17$ & $11.47 \pm 1.07$ & $87.7 \pm 7.41$ & $104.9 \pm 4.19$ \\
Dolomite-B & $5.15 \pm 0.66$ & $13.10 \pm 0.62$ & $75.7 \pm 2.10$ & $80.9 \pm 3.62$ \\
Marble-A & $7.25 \pm 1.83$ & $11.23 \pm 1.07$ & $73.8 \pm 2.32$ & $84.6 \pm 4.23$ \\
Marble-B & $9.59 \pm 1.02$ & $10.76 \pm 1.22$ & $80.9 \pm 2.75$ & $86.5 \pm 4.11$ \\
Marlstone-A & $7.80 \pm 0.95$ & $12.17 \pm 0.62$ & $78.4 \pm 6.83$ & $91.0 \pm 6.22$ \\
Marlstone-B & $7.64 \pm 1.33$ & $11.78 \pm 1.91$ & $78.3 \pm 3.41$ & $82.7 \pm 5.40$ \\
Limestone-A & $8.74 \pm 0.68$ & $11.15 \pm 0.36$ & $75.3 \pm 6.18$ & $88.5 \pm 7.78$ \\
Limestone-B & $7.25 \pm 1.53$ & $10.69 \pm 2.12$ & $96.0 \pm 2.19$ & $87.1 \pm 9.36$ \\
Feldspar-A & $6.44 \pm 1.55$ & $13.18 \pm 0.59$ & $94.7 \pm 3.76$ & $92.6 \pm 1.83$ \\
Feldspar-B & $6.05 \pm 0.89$ & $15.44 \pm 1.02$ & &
\end{tabular}

The FTIR-ATR spectra of all the studied materials are shown in Figure 1. The FTIR method is able to evaluate the geopolymer reaction by the identification of geopolymer bonds. The formation of geopolymer bonds ( $\mathrm{Si}-\mathrm{O}-\mathrm{Al}$ ) can be proven by a spectral shift of the principal band at $1080 \mathrm{~cm}^{-1}$ to lower wavenumbers [32]. This is evident in the case of the spectrum of the STJ 25 sample, in which the wavelength value decreases to $1003 \mathrm{~cm}^{-1}$. The reactions of this material with WSP do not shift the Si-O-Al band much, which means that the WSP does not engage in the geopolymer structure. The shifts are negligible with respect to resolution $\left(4 \mathrm{~cm}^{-1}\right)$.

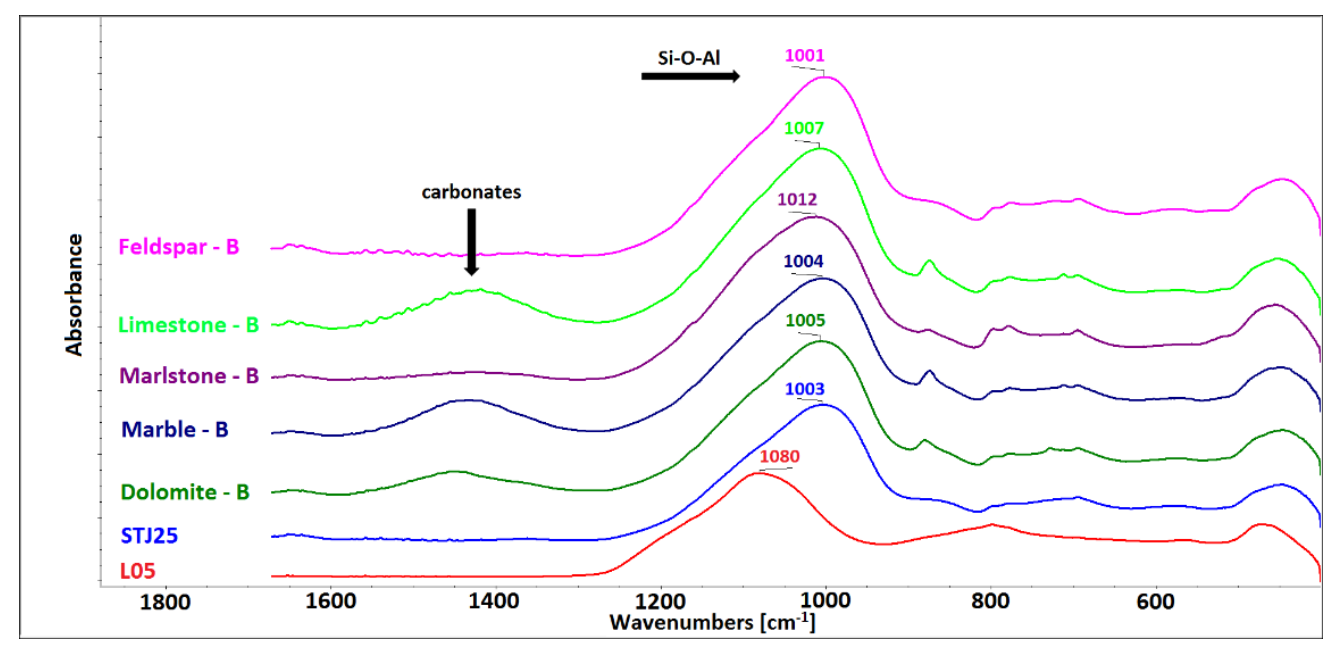

Figure 1. The FTIR-ATR spectra of the initial material (L05) and the resulting geopolymer material (STJ 25, Dolomite-B, Marble-B, Marlstone-B, Limestone-B and Feldspar-B).

The spectra of Dolomite- $\mathrm{B}$, Marble-B and Limestone-B show a band of carbonates at $\sim 1450 \mathrm{~cm}^{-1}$, which are present as the dominant component in the original reaction materials (dolomite, marble and limestone).

The textural parameters presented in Table 5 as the specific surface area and the surface of micropores provide information about pores up to $50 \mathrm{~nm}$. Activated carbon serves as the referential material only for a comparison of textural parameters. The variability of pore surfaces in the studied materials is low. Nevertheless, the relationship between the parameters $n$ and $S_{\mathrm{m}}$, shown in Table 5, is evident $\left(\mathrm{R}^{2}=0.9482\right)$. Their behavior is thus similar to the most solid natural materials $[33,34]$. 
Table 5. Textural and sorption properties.

\begin{tabular}{|c|c|c|c|c|c|c|}
\hline \multirow[t]{2}{*}{ Sample } & \multicolumn{6}{|c|}{ Parameter } \\
\hline & $S_{\text {BET }}$ & $S_{\mathrm{m}}$ & $S_{\mathrm{Hg}}$ & $P$ & $n$ & $E_{\text {sorp }}$ \\
\hline & & $\left.\mathrm{n}^{2} \cdot \mathrm{g}^{-1}\right)$ & & $(\%)$ & $\left(\mathrm{mg} \cdot \mathrm{g}^{-1}\right)$ & $\left(\mathrm{kJ} \cdot \mathrm{mol}^{-1}\right)$ \\
\hline STJ 25 & 60.6 & 108.2 & 5.2 & 6.3 & 20.8 & 14.8 \\
\hline Dolomite-B & 47.4 & 115.3 & 5.2 & 5.7 & 23.4 & 17.0 \\
\hline Marble-B & 46.7 & 98.9 & 7.5 & 6.3 & 20.1 & 16.8 \\
\hline Marlstone-B & 43.0 & 112.73 & 6.3 & 7.2 & 22.8 & 17.0 \\
\hline Limestone-B & 45.5 & 100.3 & 6.5 & 5.7 & 20.4 & 16.7 \\
\hline Feldspar-B & 52.1 & 124.1 & 5.5 & 6.9 & 24.9 & 16.5 \\
\hline $\mathrm{AcC}$ & 1343.0 & 573.1 & - & $>70$ & 75.2 & 9.7 \\
\hline
\end{tabular}

AcC-activated carbon, $S_{\mathrm{BET}}$ - specific surface area, $S_{\mathrm{m}}$ - surface of micropores, $S_{\mathrm{Hg}}$-surface of meso- and macropores, $P$-porosity, $n$-real adsorption capacity, $E_{\text {sorp }}$-adsorption energy.

Micropores are the main contributor to the total surface area and a key factor for enhancing sorption capacities. On the other hand, the meso- and macropores strongly contribute to material instability. $S_{\mathrm{Hg}}$ positively correlates with IST and FST $\left(\mathrm{R}^{2}=0.7544\right.$, $R^{2}=0.6977$, respectively). There is a strong positive relationship $\left(R^{2}=0.9102\right)$ between $S_{\mathrm{Hg}}$ and the flexural strength after 28 days; on the other hand, the trend with the flexural strength after 90 days is the opposite $\left(\mathrm{R}^{2}=0.5505\right)$, as can be seen in Figure S2A,B. The larger the surface of the meso- and macropores, the higher the flexural strength at 28 days of maturation. A possible explanation is that in a material with low maturation when the humidity is higher, the water is adsorbed in mesopores, which have space for deformation and cause some elasticity of the material. On the contrary, a higher content of micropores (see Figure S2C,D) decreases the flexural strength after $28 \mathrm{~d}$ but causes better flexural strength in longer, 90-day maturation time $\left(\mathrm{R}^{2}=0.8421\right)$ and better comprehensive strength $(28 \mathrm{~d})\left(\mathrm{R}^{2}=0.7886\right)$. It was found that the comprehensive strength after 90 days is not much affected by the presence of any type of pores.

The pore-size distribution obtained by mercury porosimetry (Figure 2) shows the prevalence of the pores below $10 \mathrm{~nm}$. It is evident that the basic geopolymer composite STJ 25 has a relatively higher volume of pores of about $250 \mathrm{~nm}$, which are, however, eliminated with the addition of WSP. The presence of larger pores is about six times lower in comparison with AcC (see Table 5). The average content of micropores in the STJ 25 is lower than in geopolymers with the addition of feldspar, marlstone and dolomite and higher than with marble and limestone added. The low porosity $(P)$ means that the material has a low content of all pores smaller than $60 \mu \mathrm{m}$. In the case of the STJ 25, the $P$-value is similar to the $P$-values of the composite materials with WSP. It is evident that the addition of WSP has not affected the textural properties of the studied composites much-they mostly depend on the properties of the basic material STJ 25.

$\mathrm{N}_{2}$ adsorption isotherms (Figure 3) confirm that the materials are microporous (the presence of pores $<2 \mathrm{~nm}$ ) and mesoporous (the presence of pores of 2-50 nm). The hysteresis curve indicates the prevailing shapes of pores, which fall into a mixed group of $\mathrm{H} 2$-inkbottle pores and $\mathrm{H} 4$ - slit- and wedge-shape pores [35,36]. The first type, H2, is usually a wide hysteresis with the inflection point at the pressure of 300-400 kPa on the desorption curve which is an indicator of ink-bottle pores with a narrow or almost closed neck. In the second type, $\mathrm{H} 4$, the shapes of pores are more open than the cylindrical pores present, for example, in AcC $[35,36]$. The types and courses of hysteresis depend on many factors, in this case on the presence of carbonates (as shown in Figure 1). Feldspar, marble, limestone and dolomite have shifted the curves to higher pressures (Figure 3A-C, which implies the presence of more open pores and a smaller share of micropores. The amount of the adsorbed $\mathrm{N}_{2}$ increases with decreasing $\mathrm{Si} / \mathrm{Al}$ ratio. Marlstone has the highest $\mathrm{Si} / \mathrm{Al}$ ratio and the lowest amount of $\mathrm{N}_{2}$ adsorbed of all the samples (Figure 3D). 


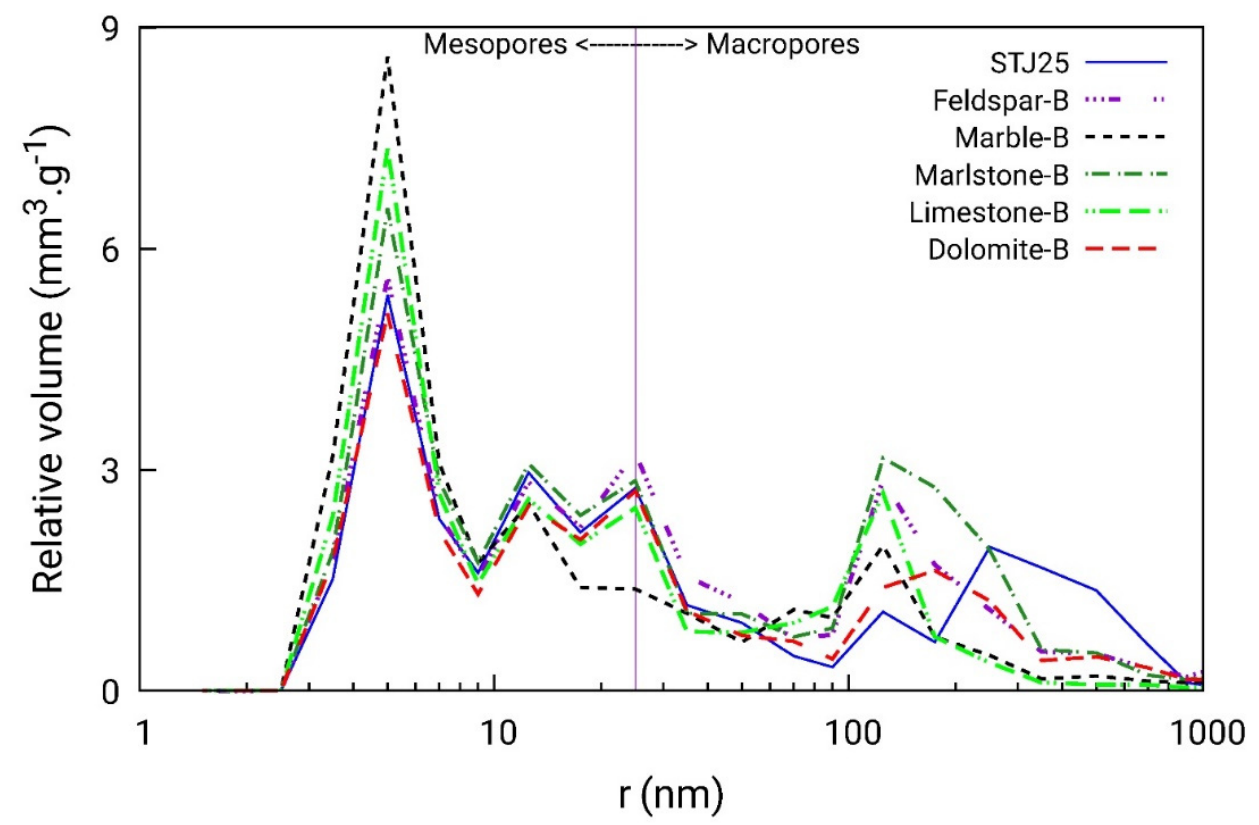

Figure 2. The pore-size distribution of samples with WSP and the clear basic mass obtained by mercury porosimetry.
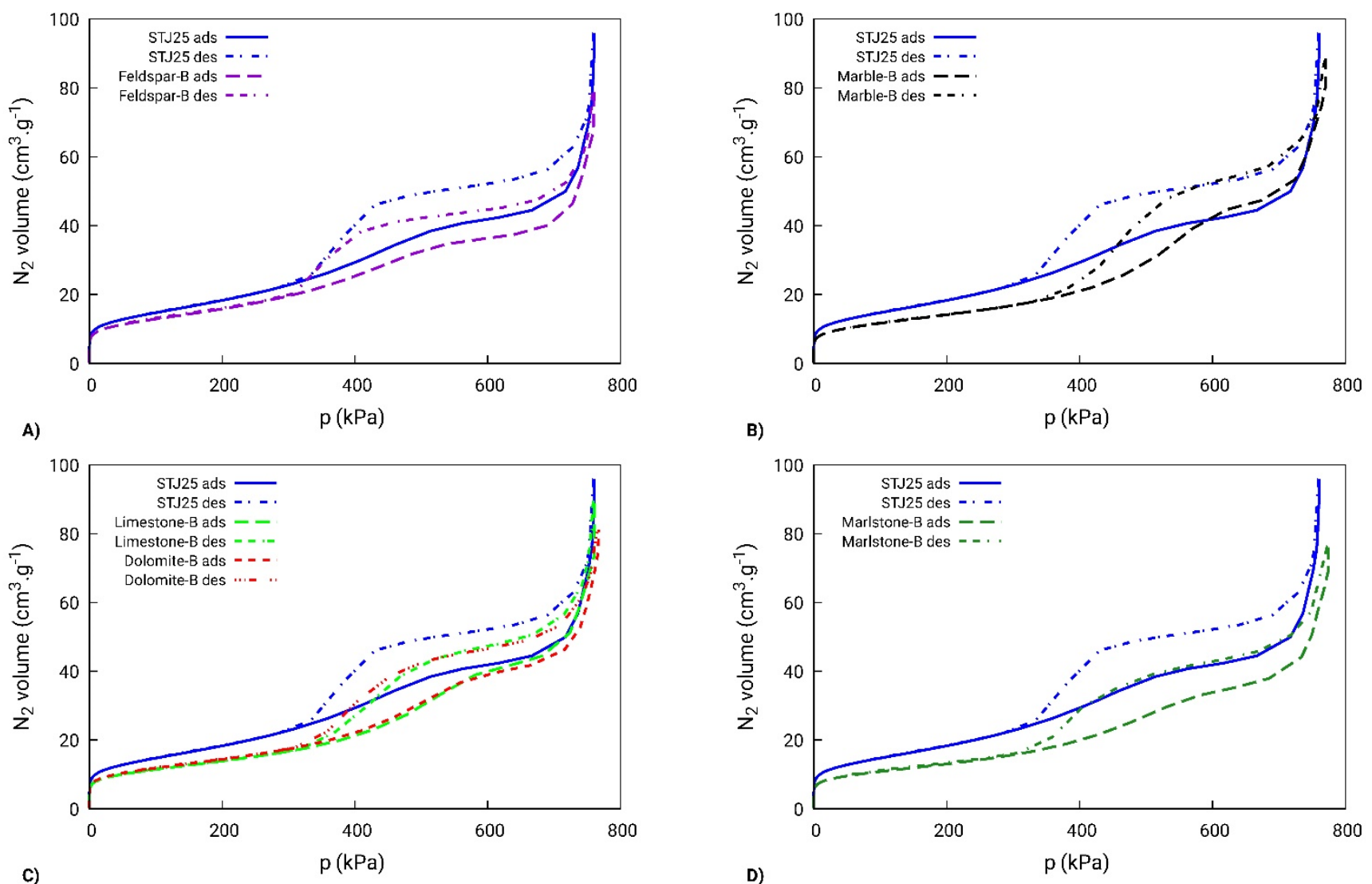

Figure 3. Nitrogen adsorption/desorption isotherms, the amount of $\mathrm{N}_{2}$ in pores in pressure steps; the four types and courses of the hysteresis loops.

Generally, in the materials studied, the molecules have worse conditions for capture on the pore surface and need to exert more energy for sorption. The worse the sorption, the greater the sorption energy. Materials with high sorption energy have poor sorption abil- 
ity $[27,37]$. As can be seen in Table 5, the activated carbon has very high porosity, because the surfaces of the pores are very large. The sorption energy of $\mathrm{AcC}$ is approximately two times lower than for composites, which is caused by the easy capture of the $\mathrm{CO}_{2}$ molecules on carbon surfaces. The ability of the studied materials to capture $\mathrm{CO}_{2}$ is low.

The sample with feldspar has a larger pore volume than others. It was observed that the feldspar content increases the micropore content in natural materials such as sediments [33]. In the case of the geopolymers concerned, the addition of the studied amount of feldspar is not high enough to change the properties of the material much.

\section{Conclusions}

The main findings of the presented results can be summarized as follows:

- Waste stone powder (WSP) was successfully used as an additive in the preparation of geopolymer composites. The composites obtained are solid, resistant and insoluble in water.

- WSP additions rather improve the compressive strengths of geopolymers in comparison with a geopolymer composite containing only quartz sand (STJ 25). The flexural strengths are positively influenced only by some of them, especially feldspar and dolomite, The B addition (10.6 wt. \%) of feldspar and dolomite increases significantly both flexural and compressive strengths, especially after 90 days.

- Setting time measurements have shown that waste stone powder can be used to accelerate the solidification of the geopolymer reaction, with the exception of dolomite, which was removed from the correlation because of its higher $\mathrm{MgO}$ content. The particle size of WSP affects the solidification time of the samples. The smaller the particles (D50), the faster the solidification of the samples (the shorter their final setting time).

- Concerning infrared spectroscopy, there is no significant shift in Si-O-Al bands, which means that the WSP is engaged in the geopolymer structure only minimally or not at all.

- The WSP does not worsen the textural properties, such as pore volumes and surfacesporosity. These remain more or less unchanged, approximately in the values of the porosity of the matrix. Only the addition of feldspar slightly increases the porosity, sorption capacity and content of micropores.

- The obtained results will make it possible to recycle WSP, which was previously landfilled, as a new source of material for the preparation of geopolymers. The use of alternative sources of raw materials plays a major role in the reduction of the environmental burden and in the pursuit of the sustainability of natural resources.

Supplementary Materials: The following are available online at https:/ / www.mdpi.com/article/10 .3390 / cryst11080983/s1, Table S1. Particle-size analyses of the different types of waste stone powder, Table S2. Mix design summary, Table S3. XRD analyses of the stone powder used, Table S4. XRD analyses of geopolymers with different types of waste stone powder, Figure S1. The dependence of solidification time on WSP particle sizes, Figure S2. The dependence of strength factors on pore content: (A) flexural strength on meso- and macropore content, (B) compressive strength on mesoand macropore content, $(C)$ flexural strength on micropore content, (D) compressive strength on micropore content.

Author Contributions: Conceptualization, I.P. and M.N.; methodology, I.P., M.̌̌. and D.̌̌.; formal analysis, I.P., M.N., M.Š. and D. ̌̌.; investigation, I.P., M.N., M.Š. and D.̌̌r.; data curation, I.P., M.N., M.Š. and D. ̌̌.; writing—original draft preparation, I.P., M.N. and D. ̌̌.; writing-review and editing, I.P., M.N. and D.ř.; supervision, I.P. All authors have read and agreed to the published version of the manuscript.

Funding: This work was carried out thanks to the support of the long-term project for the conceptual development of the research organization No. 67985891, and the Strategy AV21, the activity of the Czech Academy of Sciences, the research program VP23-City as a Laboratory of Change: Historical 
Heritage and Place for Safe and Quality Life, and the grant of Specific University Research—grant No. A1_FCHT_2021_006.

Acknowledgments: The authors would like to thank the reviewers and editor for the manuscript revision.

Conflicts of Interest: The authors declare no conflict of interest.

\section{References}

1. Havelcová, M.; Bičáková, O.; Sýkorová, I.; Weishauptová, Z.; Melegy, A. Characterization of products from pyrolysis of coal with the addition of polyethylene terephthalate. Fuel Process. Technol. 2016, 154, 123-131. [CrossRef]

2. Straka, P.; Bičáková, O.; Šupová, M. Thermal conversion of polyolefins/polystyrene ternary mixtures: Kinetics and pyrolysis on a laboratory and commercial scales. J. Anal. Appl. Pyrolysis 2017, 128, 196-207. [CrossRef]

3. Perná, I.; Hanzlíček, T.; Straka, P.; Steinerová, M. Acoustic absorption of geopolymer/sand mixture. Ceram. Silik. 2009, 53, 48-51.

4. Perná, I.; Šupová, M.; Hanzlíček, T.; Špaldoňová, A. The synthesis and characterization of geopolymers based on metakaolin and high LOI straw ash. Constr. Build. Mater. 2019, 228, 116765. [CrossRef]

5. Perná, I.; Hanzlíček, T. The solidification of aluminum production waste in geopolymer matrix. J. Clean. Prod. 2014, 84, 657-662. [CrossRef]

6. Siddique, R.; Cachim, P. Waste and Supplementary Cementitious Materials in Concrete: Characterisation, Properties and Applications; Woodhead Publishing: Cambridge, UK, 2018.

7. Singh, J.; Singh, S.P. Geopolymerization of solid waste of non-ferrous metallurgy-A review. J. Environ. Manag. 2019, $251,109571$. [CrossRef]

8. Bouna, L.; El Fakir, A.A.; Benlhachemi, A.; Draoui, K.; Ezahri, M.; Bakiz, B.; Villain, S.; Guinneton, F.; Elalem, N. Synthesis and characterization of mesoporous geopolymer based on Moroccan kaolinite rich clay. Appl. Clay Sci. 2020, 196, 105764. [CrossRef]

9. Ghani, U.; Hussain, S.; Imtiaz, M.; Khan, S.A. Laterite clay-based geopolymer as a potential adsorbent for the heavy metals removal from aqueous solutions. J. Saudi Chem. Soc. 2020, 24, 874-884. [CrossRef]

10. Lakhani, R.; Kumar, R.; Tomar, P. Utilization of Stone Waste in the Development of Value Added Products: A State of the Art Review. J. Eng. Sci. Technol. 2014, 7, 180-187. [CrossRef]

11. Mahzuz, H.M.A.; Ahmed, A.A.M.; Yusuf, M.A. Use of stone powder in concrete and mortar as an alternative of sand. Afr. J. Environ. Sci. Technol. 2011, 5, 381-388.

12. Sivrikaya, O.; Kiyildi, K.R.; Karaca, Z. Recycling waste from natural stone processing plants to stabilize clayey soil. Environ. Earth Sci. 2014, 71, 4397-4407. [CrossRef]

13. Liew, Y.M.; Heah, C.Y.; Kamarudin, H. Structure and properties of clay-based geopolymer cements: A review. Prog. Mater. Sci. 2016, 83, 595-629. [CrossRef]

14. Rashad, A.M. Alkali-activated metakaolin: A short guide for civil engineer-An overview. Constr. Build. Mater. 2013, 41, 751-765. [CrossRef]

15. Zhang, P.; Zheng, Y.; Wang, K.; Zhang, J. A review on properties of fresh and hardened geopolymer mortar. Compos. Part B 2018, 152, 79-95. [CrossRef]

16. Zhang, P.; Gao, Z.; Wang, J.; Guo, J.; Hu, S.; Ling, Y. Properties of fresh and hardened fly ash/slag based geopolymer concrete: A review. J. Clean. Prod. 2020, 270, 122389. [CrossRef]

17. Amran, Y.M.; Alyousef, R.; Alabduljabbar, H.; El-Zeadani, M. Clean production and properties of geopolymer concrete: A review. J. Clean. Prod. 2020, 251, 119679. [CrossRef]

18. Singh, N.B.; Middendorf, B. Geopolymers as an alternative to Portland cement: An overview. Constr. Build. Mater. 2020, 237, 117455. [CrossRef]

19. Xu, H.; Van Deventer, J.S.J. The geopolymerisation of alumino-silicate minerals. Int. J. Miner. Process. 2000, 59, 247-266. [CrossRef]

20. Novotná, M.; Perná, I.; Hanzlíček, T. Review of Possible Fillers and Additives for Geopolymer Materials. Waste Forum 2020, 2 , 78-89. Available online: www.wasteforum.cz (accessed on 15 June 2021).

21. Kohout, J.; Koutník, P. Effect of Filler Type on the Thermo-Mechanical Properties of Metakaolinite-Based Geopolymer Composites. Materials 2020, 13, 2395. [CrossRef]

22. Lahoti, M.; Tan, K.H.; Yang, E. A critical review of geopolymer properties for structural fire-resistance applications. Constr. Build. Mater. 2019, 221, 514-526. [CrossRef]

23. Perez-Cortes, P.; Escalante-Garcia, J.I. Alkali activated metakaolin with high limestone contents-Statistical modeling of strength and environmental and cost analyses. Cem. Concr. Compos. 2020, 106, 103450. [CrossRef]

24. Cohen, E.; Peled, A.; Bar-Nes, G. Dolomite-based quarry-dust as a substitute for fly-ash geopolymers and cement pastes. J. Clean. Prod. 2019, 235, 910-919. [CrossRef]

25. Komnitsas, K.; Soultana, A.; Bartzas, G. Marble waste valorization through alkali activation. Minerals 2021, 11.1, 46. [CrossRef]

26. Dabrowski, A. Adsorption-From theory to practice. Adv. Colloid Interface Sci. 2001, 93, 135-224. [CrossRef]

27. Brunauer, S.; Emmett, P.H.; Teller, E. Adsorption of gases in multimolecular layers. J. Am. Chem. Soc. 1938, 60, 309-319. [CrossRef]

28. Washburn, E.W. The dynamics of capillary flow. Phys. Rev. 1921, 17, 273. [CrossRef]

29. Dubinin, M.M. Adsorption in micropores. J. Colloid Interface Sci. 1967, 23, 487-499. [CrossRef] 
30. Medek, J. Possibility of micropore analysis of coal and coke from the carbon dioxide isotherm. Fuel 1977, 56, 131-133. [CrossRef]

31. Hanzlíček, T.; Steinerová-Vondráková, M. Investigation of dissolution of aluminosilicates in aqueous alkaline solution under laboratory conditions. Ceramics 2002, 46, 97-103.

32. Rees, C.A.; Provis, J.L.; Lukey, G.C.; van Deventer, J.S. Attenuated total reflectance Fourier transform infrared analysis of fly ash geopolymer gel aging. Langmuir 2007, 23, 8170-8179. [CrossRef] [PubMed]

33. Řimnáčová, D.; Weishauptová, Z.; Přibyl, O.; Sýkorová, I.; René, M. Effect of shale properties on $\mathrm{CH}_{4}$ and $\mathrm{CO}_{2}$ sorption capacity in Czech Silurian shales. J. Nat. Gas Sci. Eng. 2020, 80, 103377. [CrossRef]

34. Chouikhi, N.; Cecilia, J.A.; Vilarrasa-García, E.; Besghaier, S.; Chlendi, M.; Franco Duro, F.I.; Rodriguez Castellon, E.; Bagane, M. $\mathrm{CO}_{2}$ adsorption of materials synthesized from clay minerals: A review. Minerals 2019, 9, 514. [CrossRef]

35. International Union of Pure and Applied Chemistry (IUPAC) Manuals of Symbols and Terminology for Physico Chemical Quantities and Units; Butterworths: London, UK, 1972.

36. Li, Z.; Liu, D.; Cai, Y.; Wang, Y.; Teng, J. Adsorption pore structure and its fractal characteristics of coals by N2 adsorption/desorption and FESEM image analyses. Fuel 2019, 257, 116031. [CrossRef]

37. Barrett, E.P.; Joyner, L.G.; Halenda, P.P. The determination of pore volume and area distributions in porous substances. I. Computations from nitrogen isotherms. J. Am. Chem. Soc. 1951, 73, 373-380. [CrossRef] 